\title{
Prokofyeva S.M.
}

DOI: 10.25108/2304-1730-1749.iolr.2016.46.185-205

\section{An essence of humanism in criminal proceedings}

\begin{abstract}
In order to work out a common conception of humanization of criminal procedural relationships there should be determined a core of humanism in criminal proceedings.

Criminal procedural relationships are the legal relationships, which are formed between participants of criminal process in course of fulfillment by them criminal procedural activity.

Purpose of criminal process is humanistic, i.e. in order to achieve it should be resolved not less humanistic objectives and just: strengthening of protection of rights and freedoms of citizens, interests of society, education of respect and observance of laws, fast and completed disclosure of crimes, inculpation of guilty persons, providing exact application of law.
\end{abstract}

Keywords: criminal proceedings; legal relationships; criminal process; humanism; justice.

Criminal proceeding is one of the spheres of social relationships. Criminal procedural relationships have its specifics determining with the tasks of criminal process. In order to work out a common conception of humanization of criminal procedural relationships there should be determined a core of humanism in criminal proceedings.

There are different points of view on this matter. So, Yu.A. Lyakhov believes that under humanism of criminal process should be understood a protection of

\footnotetext{
- Prokofyeva Svetlana Mikhaylovna - Doctor of Law, Professor of the Department for criminal law of juridical faculty of Sankt Petersburg State University of marine sea and river fleet named after Admiral S.O. Makarov (Russia). E-mail: guwkup@yandex.ru
} 
citizens from criminal encroachments and belief in possibility of correction persons, who committed crime [12, p. 25]. Other authors under humanism understand a recognition of human's personality value, protection of person's honour and dignity, life and health [7, p. 143]; third - equality everybody to the law [3, p. 3-8]. First of all, we should note that the notions "criminal process" and "criminal proceedings" are identical in legal science [21, p. 7]. Under these is understood an activity all participants of process under determining role of bodies of inquiry, investigatory, prosecutor's office and a court, which directed to institution, investigation, judicial examination and resolution of criminal cases. In our view, in order to define a core of humanism in criminal proceedings we one needs to investigate: 1) what beginnings are in a base of criminal procedural relationships; 2) what kinds of humanistic relationships are implemented in criminal proceedings, and also a level of humanity of criminal process in whole. There is no opportunity to consider all moral values in frame of the present article therefore we will apply to those, which have more significant for this sphere of human activity.

Criminal procedural relations are the legal relationships, which are formed between participants of criminal process in course of fulfilling by them the criminal procedural activity directed to achievement of the aims of criminal proceedings and solution its tasks [1, p. 7]. According to the legislation, aims and objectives of criminal proceedings are stipulated in article 2 of Criminal Procedural Code (hereinafter, CPC). But, the aims and objectives of criminal process are excluded from CPC of RF. In our view, this is wrong decision in principle because any activity, including criminal procedural one, has certain goal, which is achieved through solution of concrete tasks. So, for example, the objectives are fixed in criminal law (art. 2 of Criminal Code), civil proceedings (art. 2) and other branches of the law. In this connection we are offering to restore the aims and objectives in criminal procedural legislation.

Distinction of criminal procedural relations is concluded in that from one side always acts the state in face of its public bodies and officials, who provided with 
powers, and from other one - other participants of criminal process, i.e. citizens or legal entities, who have rights and obligations. In this connection, we should make clear, whether the aims, objectives and means of criminal proceedings are corresponding to universal values.

There are existed various opinions about the aims of criminal process. So, A.F. Koni emphasized in $19^{\text {th }}$ century that justice had to have a goal of forming not only respect to law, but also to human dignity [11, p. 58]. V.E. Kvashis sees a goal of criminal process in eradication of criminality [9, p. 11], S.V. Bobotov - in carrying out fair trial [2, p. 22-23], P.S. Elkind - in realization of the norms of criminal procedural law [24, p. 20], T.N. Dobrovolskaya - in establishing of the truth [6, p. 121]. Article 2 Of CPC says that the objectives of proceedings are fulfilled with purpose of fair punishment of each committing a crime and none innocent was brought to criminal responsibility and convicted. In our view, more correctly the aim of criminal proceeding was stated by S.V. Bobotov because it is impossible a fair trial without establishing the truth, respect of human dignity etc. Unconditionally, a goal of criminal process is humanistic because to achieve it there should be solved not less humanistic tasks: strengthening of protection the rights and freedoms of citizens, and also interests of society, educating of citizen to respect and observance of the laws, fast and full disclosure of crimes, exposure of guilty persons, providing correct application of law. These aims and tasks of criminal proceedings have not in actually changed in $\mathrm{CPC}$ of RF, despite they have received new name: "Purpose of criminal proceedings" (art. 6 of CPC of RF). So, for example, purpose of criminal process is protection of the rights and legal interests of persons and organizations, victims from crimes; defence of person from illegal and unfounded accusation, conviction, restriction his/her rights and freedoms; refusal from criminal prosecution and assignment of fair punishment to guilty person; refusal from criminal prosecution of innocents, releasing them from punishment, rehabilitation of each, who was unfoundedly subjected to criminal prosecution. This one more confirms that the 
notions of aims and objectives of criminal proceedings should be restored in legislation.

However, it is not sufficiently that aims and objectives were humanistic, it is necessary to achieve them by humanistic means. In this connection, the ways and methods of their achievement should be moral. Correspondence aims, objectives and means of proceedings each other consist the problem of criminal process, which a lawmaker tries to resolve. But, some authors, for example, L.P. Rozhkova, believe that moral values in lawmaking are ignored, and just this leads society to legal nihilism [4, p. 147-148]. It is difficult to be agreed with point of view. Unlike this, many authors assert that criminal process is based on the norms of morality [10, $\mathrm{p}$. $43 ; 16$, p. 4-12]. In our view, they are absolutely right because on moral values based: first, principles of criminal process. Under principle (lat. Principle - base, alpha) is understood main rule of behaviour, which distribute its provisions in all phenomena of any sphere. Part of criminal procedural principles determine a nature of interrelations between participants of criminal proceedings, for example, fixed in acting legislation a principle of comprehensiveness, completeness and objectiveness of examination of case's circumstances (art. 20 of CPC). Humanistic sense of the principle is concluded in that an investigator, an inquiry officer, prosecutor and court have to establish all circumstances on criminal case: event of crime; guilt of a person committed crime; circumstances, mitigating and aggravating his/her punishment; character and size of damage caused by crime, and other circumstances having significance for correct resolution of a case. Wherein, persons indicated should be refused from any prejudices, stamps, and exigencies, to be unbiased, and make a decision on ground of not one, but few evidences received from various sources, which provided by law [20, p. 45-46]. This principle directed to fulfillment of such humanistic value like objective truth, under which is understood correct and adequate reflection of the subjects and phenomena reality by perceptive subject [22, p. 189]. Lawful and substantiated verdict might be delivered only under establishing of objective truth $[15$, p. 61$]$. It is necessary to note that this principle has been excluded 
from CPC of RF. In our opinion, this is a wrong decision. Anyway, indicated principle acts and will be acted in practice because a core and spirit of this principle have remained in other norms of CPC of RF: duty to make clear all circumstances of a case subjecting to proving (art. 73), duty to check the circumstances through comparison them with other available evidences (art. 87) etc.

Natural rights of man, which are the most important humanistic values, have been realized in criminal procedural principles. So, human right to freedom has been reflected in principle of inviolability of person (art. 11 of CPC, art. 10 of CPC of RF); right to privacy - inviolability of home, protection of person's life of citizens and secret of correspondence (art. 12 of CPC; articles 12, 13 of CPC of RF) etc. but some jurisprudents believe that the right is the norms, which fixed in law, and all other cannot be named by law. Therefore, natural right, which not fixed in law, is false one [8, p. 57]. In this fact we should note that indicated point of view contains correct indication in the fact that rights of participants of criminal proceedings have to have social guarantees, which might be only achieved through their fixation in legislative acts. But, in our view, non-fixation some natural human rights in law does not mean that they do not exist. Our point of view is confirmed by part 1 of article 55 of Constitution of RF, where is indicated that "enumerating in Constitution of Russian Federation the main rights and freedoms should not be interpreted like denial or disparagement of other common recognized rights and freedoms of man and citizen".

Natural rights of man are wider reflected in CPC of RF: first time, such principles of criminal proceedings like respect of honour and dignity of a person (art. 9), presumption of innocence (art. 14) and others are formulated in criminal procedural legislation. Indicated principles have great significance for protection of the rights of man and citizen. So, moral sense of principle of evidences' assessment is concluded in that making a decision on criminal case, a person, who carries out criminal proceedings, is guided by inner conviction and his/her conscience. V.N. Osipkin and V.I. Rokhlin rightly emphasize that "speaking about inner conviction 
under evidences' assessment, we keep in mind that approach to collected evidences should be impartial, independent on anybody's influence" [13, p. 25-26].

Second, criminal procedural relationships are regulated with the norms of law based on the norms of morality. Fairness is the most important moral value in criminal proceedings. As ago as D. Diderot, greater humanist, wrote that "fairness is related to justice like a reason to effect, and justice is nothing less than like an expression of fairness" [5, p. 348].

There is existed various points of view in respect of fairness of proceedings. So, D.P. Kotov believes that fairness in criminal process is concluded: in unavoidability of criminal responsibility for guilty persons; in protection of citizens from unfounded bringing to criminal responsibility; in their full rehabilitation and compensation their damage for caused harm; in providing of rights and legal interests of all participants of criminal process, and also interests of society; in conformity of seriousness of committed crime and person of defendant of chosen him/her measure of punishment. According to other point of view, fairness is concluded in correspondence between the rights and obligations of man [17, p. 7]. These judgements are completely correct and draw attention to objective side of fairness [10, p. 30-31]. But some authors make accent in subjective understanding of fairness. So, N.K. Petrovsky believes that each participant of criminal process has his/her imagination on fairness: for victim - the protection his/her violated rights, for defendant - determination of level his/her guilt and measure of punishment [14, p. 47]. We should note that N.K. Petrovsky is right in that sense that fairness might not be abstract notion, it is always a concrete. Therefore, the same decision in one situation might be fair, and in other - no.

In order that decisions would be fair, they should be assessed as from legal point of view so from moral one. Up to the present there is no indication in valid legislation that a verdict must be fair (art. 301 of CPC). CPC of RF eliminated this gap and introduced requirement of verdict's fairness (art. 297). But independently the principle of fairness is not presented in CPC of RF. In our view, this approach of a lawmaker should be recognized unfounded because fairness is universal category and 
compiles one of the main humanistic principles of criminal process. Justice cannot exist without fairness. On this reason, it is reasonable to include fairness in a list of the principles of criminal process like universal value.

As it stated above, aspiration to development of human individuality and freedom is an indicator of humanity of society. This idea has direct attitude to criminal proceedings. So, problems of humanization of criminal process require an individual approach to a person, who committed crime: under application to him/her coercion's measures; determination of kind and size of punishment; creation humanlike conditions for citizens taking in custody in order not to separate them from cultural life of society and provide access to mass media, scientific and fiction literature.

Third, criminal procedural relations provide such significant humanistic value like man's right to communication. Under communication is understood a form of human interaction, in process of which happens exchange of activity, information, experience, abilities, emotions, different spiritual values [23, p. 75]. Man cannot fully be developed out of communication. He/she assimilates life and gained by humanity experience through communication. As ago as Seneca said: "Remove sociability and you separate unity of human kind, in which human's life is based on". It is necessary to note that just through communication a man manifests his/her attitude to other people and realizes their attitude to him

Fourth, the norms of morality fixed in consciousness of subjects of criminal procedural relationships are acting in criminal proceedings. These norms impact in behaviour of indicated persons and manner of their communication with other participants of process. Observance of morality's norms by officials is manifested in tactful addressing with all participants of criminal proceedings, in satisfaction of all founded petitions, in calm and correct tone like under addressing to an accused person so to a victim, in attentive hearing of testimonies etc. Certainly, official, who carrying out criminal proceedings, feels compassion to victim and he/she is disgusted illegal behaviour of accused. Ability to sympathy and compassion should always be 
inherent to official. Indifference and apathetic attitude to accused and victims testify about soulful roughening, losing moral feelings, and professional deformation of this person. But, as it rightly noted by V.I. Sokolvsky, an employee has to be guided in each situation with mind but not feeling and emotions [19, p. 73]. In fact, emotions have no gush over and disturb impartial making of decisions. Official has to respect and to observe the rights of participants of criminal process provided them by law.

Thus, we see that there is inseparable link between the norms of right and the norms of morality in criminal process. Morality presents a moral right in form of necessity, unwritten law, at the same time the right regulates behaviour of peoples through certain norms, which established in society and fixed in law.

\section{References}

1. Averin A.V. Pravootnoshenie i sudebnaya praktika [Legal relationships and judicial practice]. Avtoref. dis... kand. yurid. nauk [PhD in Law Diss. Abstract]. Saratov, 1994, 23 p.

2. Bobotov S.V. Sotsial'nyi mekhanizm burzhuaznoi ugolovnoy yustitsii [Social mechanism of bourgeois criminal justice]. Avtoref. dis... dokt. yurid. nauk [Doct. Law Diss. Abstract]. Moscow, 1979, 43 p.

3. Gumanizm sovetskoy Konstitutsii [Humanism of soviet Constitution]. Lekts. metod. razrabotka [Lectures, guidelines]. Moscow, 1978, 89 p.

4. Demokratiya i zakonnost': problem razvitiya i sootnosheniya [Democracy and lawfulness: problems of development and correlation] red. L.P. Rozhkov [ed. by Rozhkov], Samara, 1991, 164 p.

5. Didro D. Entsiklopediya ili Tolkovyi slovar' nauk, iskusstva i remesel [Encyclopedia or Explanatory dictionary of sciences, arts and crafts]. Moscow, 1994.

6. Dobrovol'skaya T.N. Printsipy sovetskogo ugolovnogo protsessa [Principles of soviet criminal process]. Moscow, 1971, $124 \mathrm{p}$. 
7. Epifanov B.V. Printsip sotsial'noy spravedlivosti v ugolovnom prave [Principle of social fairness in criminal law]. Dis... kand. yurid. nauk [PhD in Law Diss.]. S. Petersburg, 1993, $182 \mathrm{p}$.

8. Istoriya, filosofiya, printsipi i metody pravozaschitnoy deyatel'nosti [History, philosophy, principles and methods of human rights activity] Sb. Materialov seminara Mosk. Khel's. gruppa "Prava cheloveka", 1-4 fevralya 1991[Col. of materials of Moscow Helsinki group "Human rights", 1-4 February 1991]. Sost. i obsch. red. Bogoraz [Col. and ed. by Bogoraz]. Moscow, 1995, 47 p.

9. Kvashis V.E. Gumanizm sovetskogo ugolovnogo prava [Humanism of soviet law]. Moscow, 1969, 150 p.

10. Kokorev L.D., Kotov D.P. Etika ugolovnogo protsessa [Ethics of criminal process]. Voronezh, 1993, $222 \mathrm{p}$.

11. Koni A.F. Nravstvennye nachala $\mathrm{v}$ ugolovnom protsesse (Obschie cherty sudebnoy etiki) [Moral beginnings in criminal process (common features of ethics)]. Izb. proiz. v 2 t. T. 1. [Selected works in 2 vol., vol. 1] Moscow, 1959, 222 p.

12. Lyakhov Yu.A. Novaya ugolovno-protsessual'naya politika New criminal procedural policy]. Rostov, 1992, 96 p.

13. Osipkin V.N., Rokhlin V.I. Dokazatel'stva [Evidences]. S. Petersburg, 1998, $32 \mathrm{p}$.

14. Petrovsky N.K. Verdikt prisyazhnykh zasedateley i ego social'no-pravovye posledstviya [Verdict of jurors and its social and legal results]. Dis... kand. yurid. nauk [PhD in Law Diss.]. S. Petersburg, 1998, 198 p.

15. Poteruzha I.I. Vospitatel'no-predupreditel'noe znachenie sudebnogo razbiratel'stva ugolovnykh del [Educational preventive significance of judicial proceedings of criminal cases]. Minsk, 1976, $139 \mathrm{p}$.

16. Pokhmelkin V.V. Printsip gumanizma i ugolovno-pravovoe prinuzdenie [Principle of humanism and criminal legal coercion]. Pravovoe prinuzhdenie $\mathrm{v}$ bor'be s prestupnost'yu [Legal coercion in fight against crime]. Moscow, 1989, 187 p. 
17. Printsip spravedlivosti pri osuschestvlenii pravosudiya po ugolovnym delam [Principle of justice at course of administration of justice on criminal cases]. Mezhvuzovsky tematicheskii sb. nauchnykh trudov. Red. kol. V.P. Nazhimov [Interuniversity thematic collection of sci. works, ed. by V.P. Nazhimov], Kaliningrad, 1990, 259 p.

18. Sokolovsky V.I. O roli ugolovnogo sudoproizvodstva $\mathrm{v}$ formirovanii professional'noy etiki sotrudnikov vnutrennikh del [On role of criminal proceedings in formation of professional ethics of employees of internal affairs bodies]. Sb. Nauchykh trudov [Col. of sci. works]. Leningrad, 1986, 189 p.

19. Stolyarenko A.M. Yuridicheskaya pedagogika v sisteme MVD: Metodologiya, teoriya, praktika [Legal pedagogy in system of the MIA: Methods, theory, practice]. Dis. dokt. pedag. nauk [Doct of Ped. Sci. Diss.]. Moscow, 1999, 496 p.

20. Ugolovnyi protsess: Kurs lektsii. Pod red. V.I. Rokhlina [Criminal process: Course of lectures, ed. by V.I. Rokhlin]. S. Petersburg, 2001, 208 p.

21. Filosofsky entsiklopedichesky slovar' [Philosophic Encyclopedic dictionary]. Redaktory-sostaviteli: E.F. Gubsky, G.V. Korableva, V.A. Lutchenko [ed. by E.F. Gubsky, G.V. Korableva, V.A. Lutchenko]. Moscow, 2001, 576 p.

22. Chelovek i obschestvo [Man and society]. Uchebnoe posobie / Pod red. I.I. Kal'nogo i T.N. Titovoi [Manual ed. by I.I. Kal'nyi and T.N. Titova]. Simferopol, 1994, 286 p.

23. Elkind P.S. Tseli I sredstva ikh dostizheniya $\mathrm{v}$ sovetskom ugolovnoprotsessual'nom prave [Goals and means their achievement in soviet criminal procedural law]. Leningrad, 1976, $142 \mathrm{p}$. 